\begin{tabular}{|l|l|l||}
\hline \multicolumn{2}{|c|}{ PublisherInfo } \\
\hline \hline PublisherName & $:$ & BioMed Central \\
\hline \hline PublisherLocation & $:$ & London \\
\hline \hline PublisherImprintName & $:$ & BioMed Central \\
\hline \hline
\end{tabular}

\title{
Chemokines may be used in metastasis
}

\begin{tabular}{|l|l|l||}
\hline \multicolumn{2}{|c|}{ ArticleInfo } \\
\hline \hline ArticleID & $:$ & 4004 \\
\hline \hline ArticleDOI & $:$ & $10.1186 /$ gb-spotlight-20010308-02 \\
\hline \hline ArticleCitationID & $:$ & spotlight-20010308-02 \\
\hline \hline ArticleSequenceNumber & $:$ & 75 \\
\hline \hline ArticleCategory & $:$ & Research news \\
\hline \hline ArticleFirstPage & $:$ & 1 \\
\hline \hline ArticleLastPage & $:$ & 2 \\
\hline \hline & & RegistrationDate : 2001-03-08 \\
ArticleHistory & $:$ & OnlineDate $\quad$ 2001-03-08 \\
\hline \hline ArticleCopyright & $:$ & BioMed Central Ltd2001 \\
\hline \hline ArticleGrants & $:$ & \\
\hline \hline ArticleContext & $:$ & 130592211 \\
\hline \hline
\end{tabular}




\section{Kenneth Lee}

Email: kenlee_fr@yahoo.fr

Tumour cell migration has many similarities to leukocyte trafficking, a process by which leukocytes are recruited to sites of infection. Because chemokines - a family of small cytokines - help guide leukocytes to where they are needed, a group led by Albert Zlotnik of the DNAX Research Institute in California looked to see if chemokines also guide tumour cells to their targets.

In 1 March Nature, Zlotnik and colleagues report that the chemokine receptors CXCR4 and CCR7 are highly expressed in breast cancer cells, malignant breast tumours and metastases. The ligands of these receptors are found to be expressed at peak levels in lymph nodes, lung, liver and bone marrow - the first destinations of metastasising breast cancer cells (Nature 2001, 410:50-56). When mice injected with breast cancer cells were also treated with neutralizing anti-CXCR4 antibody, metastasis to the lung and lymph nodes was impaired significantly $(P<0.001)$.

The authors believe their findings are not limited to breast cancer - malignant melanoma cells express high levels of the chemokine receptor CCR10 in addition to CXCR4 and CCR7. Thus, antagonists of chemokine receptors might be effective in stemming tumour progression and metastasis in cancer patients.

\section{References}

1. DNAX Research Institute, [http://www.sp-research.com/aboutsp.html]

2. Müller A, Homey B, Soto H, et al:Involvement of chemokine receptors in breast cancer metastasis. Nature 2001, 410:50-56., [http://www.nature.com/nature/]

This PDF file was created after publication. 